\title{
Discussion on the Impact of Sino-US Trade War on Taiwanese Manufacturing
}

\author{
Jui-Lung Chen ${ }^{1}$ \\ ${ }^{1}$ Department of Business Administration, National Chin-Yi University of Technology, Taiwan, R.O.C \\ Correspondence: Jui-Lung Chen, Department of Business Administration, National Chin-Yi University of \\ Technology, No.57, Sec. 2, Zhongshan Rd., Taiping Dist., Taichung 41170, Taiwan, R.O.C. E-mail: \\ leonchen@ncut.edu.tw
}

Received: April 30, 2019

Accepted: May 30, 2019

Online Published: June 8, 2019

doi:10.5539/ijbm.v14n7p70

URL: https://doi.org/10.5539/ijbm.v14n7p70

\begin{abstract}
When US President Donald Trump signed the Section 301 Investigation in March 2018, the Sino-US trade war intensified, exerting a great impact on the global economy. The Trump Administration recently has piled up the economic and trade pressure on China, while China seeks to resort to the WTO dispute settlement mechanism and break the siege imposed by the trade war through the "Belt and Road Initiative". US launched a trade war against China due mainly to the huge trade deficit with China, and the trade frictions between the U.S. and China have caused turbulence on the Asian and global industrial chains. Therefore, by analyzing the recent trade conflicts between the U.S. and China and the responses given by both respectively, this paper explores the possible impact on Taiwan's manufacturing and its potential response.
\end{abstract}

Keywords: Section 301 Investigation, Sino-US Trade War, Belt and Road Initiative, Taiwan's manufacturing

\section{Introduction}

The global economy and trade are thriving but a string of problems have occurred consequently, including the trade war that all countries should work to prevent. Trade is one of the most sensitive and important issues between the U.S. and China. As bilateral trade gains momentum, trade disputes and frictions between the U.S. and China are also fueling (Kao, 2012a; Kao, 2012b). Lin (2018a) suggested that the trade war started when two countries levied high tariff on a certain range of industries and commodities. If negotiations fail to ease the friction, an embargo on commodities between both countries ensue. The worst consequence of such friction is the economic war on exchange rate, currency and capital, which goes far beyond the commodity and trade. After the Trump Administration came into power, it has repeated the accusation on the unfair trade between China and the U.S., and also highlights the trade deficit by withdrawing from Trans-Pacific Partnership Agreement (TPP), initiating a new round of discussion on the North American Free Trade Agreement (NAFTA) and raising import tariffs on steel and aluminum products. The increasing punitive tariff imposed in July 2018fueled the trade tensions between the U.S. and China (Lai, 2018; Wu, 2018; Yan, 2018; Lian, 2019). In 2017 the Trump Administration imposed Section 201, Section 232 and Section 301 on China, the trade investigations respectively on solar modules, steel and aluminum, intellectual property rights and technology transfer. The U.S. waged a trade war against China mainly because of its huge trade deficit with China. Under the continuously intensifying trade frictions between the U.S. and China, the U.S. implemented the "Section 301 Investigation" that aimed to reverse the Sino-U.S. trade deficit and strengthen industries in the U.S.As a result of the frequent protectionism, reversing trade deficits and terminating unfair trade seem to be Donald Trump's current priority (Wang, 2018; Wu, 2018). Chang (2018b) held that the Sino-U.S. trade dispute goes far beyond resolving the U.S. trade deficit. In fact, it is the rival between the U.S. and China for the global hegemony. To this end, Trump announced in early 2018 that high tariff would be imposed on steel and aluminum imposed by the US, followed by an announcement of punitive tariff of up to $\$ 60$ billion per year on Chinese products. In response, China has also threatened to take retaliatory measures. The recent growth and decline of power between the U.S. and China are not only showed in the huge trade deficit, but also in a wide range of areas such as currency, intellectual property rights, high-end technology manufacturing and military confrontation in South China Sea (Chang, 2018b; Lian, 2019).

In retrospect, the U.S. has waged various trade wars against different countries, and the trade frictions between 
the U.S. and China have caused turbulence on the Asian and global industrial chains. An export-oriented area, Taiwan's participation rate in the global value chain is $67.6 \%$, ranking second only after Luxembourg. Taiwan's manufacturing in Mainland has been affected by the triangular trade with the U.S. Due to its close economic and trade relations with the U.S. and Mainland, the triangle trade is an important pillar underpinning Taiwan's economy, so Taiwan's involvement in the Sino-U.S. trade war is virtually inevitable (Kao, 2018a; Li, 2018; Yan, 2018). As the trade war between the U.S. and China intensifies, the whole world may be affected by the crisis caused by the conflict between the two major global economies. Taiwan, which is highly dependent on foreign trade, naturally cannot be immune to such crisis, especially when the crisis is engendered by the U.S. and China, the two most important export destinations of Taiwan. Thus, Taiwan must pay great attention to the trade war between the U.S. and China (Chang, 2018a). Therefore, this paper analyses the recent trade conflict between the U.S. and China and their respective response, the impact on Taiwan and the potential countermeasures of Taiwan's manufacturing.

\section{Literature Review}

The Sino-U.S. economic and trade issues include trade deficit, exchange rate, investment and intellectual property rights, the most important of which is the Sino-U.S. political and economic problems caused by the bilateral trade and deficit. Kao (2018a) stated that the theoretical basis of free trade lies in "comparative interests", and that the specialized division of labor among the economies in pursuit of comparative interests increases the value of commodities, thereby improving the productivity of the economies, diversifying consumers' choices and creating more wealth. However, the open free trade will impact existing industries by leaving many workers unemployed or forcing them to work in a new sector, so the wealth under free trade is actually at the cost of "the impacted victims". Nevertheless, the global situation so volatile that regional conflicts will inevitably affect trade. The Sino-U.S. trade deficit had existed before Donald Trump came to power, so it has been a long-standing problem. In order to solve the unfair trade between the U.S. and multiple countries, the Trump Administration has used various means to assist damaged domestic industries (Kao, 2012a).

The Chinese government has long nourished trade through subsidies, enabling Chinese vendors to expand their markets at prices inferior to those of foreign vendors. In 2009, China surpassed Germany as the world's largest exporter; in 2010, it replaced Japan as the world's second largest manufacturer and the world's largest foreign exchange depositor; in 2012, it replaced the U.S. as the world's largest trading country (measured by the total exported and imported goods) ( $\mathrm{Wu}, 2018$ ). The Trump Administration has repeatedly accused China of manipulating exchange rate and stealing jobs and intellectual property rights from the U.S. During the election campaign, Donald Trump held up the flag of "American First" and "bringing manufacturing back to the US" and "creating jobs" were his slogan and action guideline throughout the election. In order to secure the U.S. national interests, Donald Trump believes that only by re-evaluating the U.S. trade agreements and policies and curbing unfair trade measures taken by trading partners, can the employment opportunities of U.S. citizens be guaranteed, thus making the U.S. great again. The Section 232 Investigation on the Effect of Imports of Steel on U.S. National Security directly states that China is the main source of global overcapacity. In order to solve the problem of aluminum dumping, the U.S. Department of Commerce has adopted the dual measures of anti-dumping and balanced tax against China. Therefore, in March 2018, the Trump Administration announced that the U.S. would impose punitive tariffs on steel and aluminum products. In addition, the U.S. Trade Representative (USTR) announced in April 2018 a sanction list of "301 items". Covering a wide range of industries such as aerospace, communications, robotics and machinery, this list was proposed to impose an additional $25 \%$ tariff on over 1,300 Chinese products exported to the US, totaling approximately $\$ 50$ billion. After the U.S. 301 sanction order was issued, China immediately announced its countermeasures by imposing an additional 25\% tariff on a total of 106 products imported from the US, an estimated amount of roughly $\$ 50$ billion (Chang, 2018a; Wu, 2018; Yan, 2018).

As the bilateral economic and trade exchanges tightens, trade disputes have ensued. From 1980 to 1990, the U.S. frequently used the Section 301 Investigation to tackle the unfair trade with its trading partners. This time the U.S. used the Section 301 Investigation as a tool to solve the Sino-U.S. trade deficit or strengthen the protection of its domestic industries. The goals of many current U.S. policies are the same, that is, to force China back to the negotiation table. Once both sides reap no benefits from the sanctions on commodity and trade, the war may spread to other areas such as exchange rate market, monetary policy and even punitive measures targeting on certain enterprises or specific commodities. Embargo may be the worst consequence of this war, bringing about huger and more profound impact on the global economy (Lin, 2018a; Lin, 2018b; Wang, 2018). Recent years have seen the rapid economic growth of China. Thanks to the large market of domestic demand and the government's favorable policies for high-tech manufacturing industry, the national strength of China has been 
enhanced. The Trump Administration continues to increase the economic and trade pressure on China, while China tries to break the siege of trade war through the "Belt and Road Initiative" (Lin, 2018a; Tsai, 2019). Taiwan is a region highly dependent on foreign trade and export is the cornerstone of its economy. Both the U.S. and China are Taiwan's main trading partners. Many Taiwanese enterprises receive orders in Taiwan, manufacture in China and export products to the U.S. The fierce trade war between the two economies will inevitably affect Taiwan and the development of related industries, especially in the industries of communications, electronic components, machinery and electrical equipment (Kao, 2018b).

\section{Research and Analysis}

Kao $(2010 ; 2012 a)$ pointed out that trade has become one of the most sensitive issues in US-China relations as China continues to grow economically. However, even though both sides have repeatedly expressed their intention to retaliate against each other, bilateral trade has not been interrupted or a trade war has not erupted. On the contrary, China and the U.S. are highly interdependent in exchanges like economy and trade. The bilateral trade frictions are rooted in the U.S. domestic economic imbalances, which make it difficult to ease in a short run. The U.S. frequently imposes difficulties on China's exports to it on the basis of the huge trade deficit caused by the "unfair trade practices" by the Chinese government and manufacturers (Hu, 2006). Donald Trump advocates fair trade and attributes the loss of U.S. manufacturing jobs, declining competitiveness and underperformed economy to the huge trade deficit caused by unfair trade. In order to make U.S. great again, Donald Trump did not hesitate to start an international trade war, which focuses on China's unfair competition and long-term competitiveness. The Trump Administration's stance on international trade issues is a series of actions that may lead to unfair competition under the banner of "free and fair trade", such as to require rival countries to open their markets, oppose government subsidies, manipulate exchange rate, force technology transfer and infringe intellectual property rights (Wu, 2018; Tsai, 2019). The US-China trade is not only haunted by the existing problems of bilateral trade surplus, tariff barriers and non-tariff trade obstacles, but also the technological development and future market rivalry, as well as geopolitical and economic hegemony that aims to grab resources (Kao, 2018a). The impact of the current economic and trade confrontation between China and the U.S. has not been confined to both economic systems. The changes of political and economic orders that may be caused by the confrontation have also emerged. At the beginning of the confrontation, although the conflict was believed to be resolved on the negotiation table given that both the U.S. and China were seeking a win-win result without intention of fueling the war, their diverged core objectives keep the subsequent negotiations in uncertainty (Chang, 2018b).

U.S. occupied a relatively dominant position in the trade war, so it was also strategically dominant. The "trade war" is essentially the competition of "national economic strength". The U.S. has also mentioned the "Made in China 2025" in many official trade investigation reports, demanding that China protect the intellectual property rights of U.S. companies and immediately stop subsidizing the advanced technologies covered by the "Made in China 2025" initiative. Both sides are trying to prevent the worst and strive for the best. To prevent the worst is to prevent the cold war and keep both sides from falling into the cold war mentality. If everything is measured by the defeat of one side on the other, both sides will be excessively ideologized and it is impossible to discuss rationally or strike a balance (Jia, 2018; Lin, 2018b). Jia (2018) suggested that China should respond rationally by preventing the worst consequences of the cold war mentality and striving for the best. While China is in pursuit of "peaceful rise" in the middle of the Sino-U.S. rivalry, we should grasp the correct path of catching up with other countries by holding a proper strategic thinking and keeping strategic patience with innovative thinking. However, the more significant and far-reaching impact may be exerted on Taiwan and other involved countries as the long-term Sino-U.S. trade confrontation continues. The U.S. strategy to block China's rise in economy and trade is getting clearer. Its intention to ensure its dominant position in a high-tech and AI era will not change. Meanwhile, China's adhesion to "Xi's ideology", "Made in China 2025" and national capitalism will remain unchanged, so such trend of confrontation may be lasting (Yan, 2018).

The trade disputes between the U.S. and China is essentially the conflict of economic system and development. At this stage, the key trigger point is the "Made in China 2025", the central target of U.S. tariff imposition. Apart from strengthening the control over the export of high-tech products to China, the U.S. also restricts China's investment in aerospace, robotics and electrical vehicles (Wu, 2018). Kao (2018a) indicated that although Donald Trump's aluminum special tax has a considerable impact on Taiwan's steel and aluminum alloy products, the electronic industry of Taiwan will be the primary victim if the Sino-U.S. trade war continues to intensify in the future. The proposed list of taxable products of the Section 301 Investigation issued by the Office of the U.S. Trade Representative (USTR) mainly targets on the high-tech projects of "Made in China 2025", while the Taiwan-funded telecommunications industry will suffer little, thanks to its completion of global layout. For 
Taiwan, the major impact may be experienced by small- and medium-sized Taiwanese businesses who invest and manufacture in China and sell their products to the U.S., and those who serve as an intermediary agent for the re-sale from China to the U.S. Therefore, if the U.S. implements trade protectionism, the export of Taiwanese small- and medium-sized enterprises (mainly in traditional industries) may decline (Chang, 2018a). Taiwanese businesses who trade with China on products in the list of additional tariff will be directly or indirectly affected by the Sino-U.S. trade war, regardless of the presence of their factories in China. According to the list, the goods subject to the additional tariff include steel, aluminum, industrial machinery, machine components, and equipment and components for manufacturing semiconductors. In general, the Internet communications, mid-and low-level bicycles, petrochemical products, tool machines and even semiconductor equipment and zero-resistance components exported from Mainland and Taiwan to the U.S. are most vulnerable (Li, 2018). For Taiwan, apart from the motor and electronic industries, the cross-strait industrial chains of automobile industry and textile industry feature vertical and horizontal division of labor. One mode is that manufacturers provide semi-finished component products that are finished in China; the other one is the intermediary services that sell what is manufactured in China to the US, such as automobile components and LCD TV panels. Take the automobile industry as an example. Taiwan carries out $R \& D$ and production of high-end components; China is responsible for low-level production and delivery to European and American automobile factories (Kao, 2018b).

As the tariff imposed by both the U.S. and China follow the "principle of origin" stipulated by WTO, Taiwanese businesses must have a thorough understanding of this principle in response to the additional tariff imposed amid the Sino-U.S. trade war. Machinery industry is Taiwan's major economic force. Due to the close trade relationship between Taiwan and Mainland, after the export of intermediate materials produced by Taiwan, such as components, to Mainland, U.S. will eventually be the destination of export. If trade sanctions target on export, Taiwanese enterprises will inevitably be affected, either positively or negatively. The economic operation of the US-Mainland-Taiwan triangle has been the economic development model of Taiwan over the past decades. Under this model, the U.S. orders, Taiwan receives orders and Mainland manufactures and delivers. There is a strong triangular trade relationship among the U.S., Mainland and Taiwan. For example, Taiwan exports components and semi-finished products to China where they are processed and manufactured as finished products and sell to the U.S. Vendors following this model will be directly impacted, and huger impact is experienced by Taiwanese manufacturers that directly set up factories and produce in Mainland and sell their products to the U.S. Therefore, considering the affected industries and manufacturers, many Mainland-based enterprises have shifted orders or production capacity to the surrounding areas. Recent years have seen the rise of China's red supply chain, which has transformed the complementary cooperation mode with Taiwan's supply chain into a competitive relationship. This is why the additional tariff in this trade war benefits the Taiwanese vendors, in that it increases the cost of Chinese manufacturers competing with their Taiwanese counterparts in the U.S. market and grants the latter the effect of order transfer. Chang (2018a) pointed out that due to Taiwan's effort to reduce its dependence on cross-strait economic and trade in recent years, the Sino-U.S. trade dispute does not impact Taiwanese vendors directly. However, due to the vertical division of labor and strategic cooperation between Taiwan's industries and China's manufacturers, many key component or raw material suppliers have been affected. Nevertheless, in order to reduce risk, some international large brands or vendors increase their purchase from Taiwan, giving rise to the effect of order transfer. If Taiwan reaps benefits from the effect of order transfer, the origin of this force, either from Mainland or other regions, will have a significant impact on the future economy and trade of Taiwan. However, Chang (2018a) also argued that in terms of machinery products, Taiwan's export of machinery and tool machines to China focuses on the domestic demand market, the impact on which is estimated to be scarce. Taiwan's tool machine manufacturers have never relied heavily on orders from large enterprises. In the future as long as they do not violate the Strategic Trade Control Agreement (STC), almost all of them can scatter their exports to various countries in the world, enabling these enterprises to suffer less from the Sino-U.S. trade war. In addition, unlike Taiwan's electronic industry that is deeply connected with China's supply chain, Taiwan's industries of household appliances, heavy power (transformers, wires and cables), machinery, tools, monitors, industrial computers, vehicles and automobile components, still have their main production bases in Taiwan. Even if production bases are established in Mainland, they mainly aim to supply the domestic demand of China, so the impact on these industries is also limited.

\section{Results and Discussion}

The Sino-U.S. economic and trade relation is one of the most striking issues amid the rise of China's economic strength, exerting a profound impact on the Sino-U.S. bilateral relations and even on the changes of global economy and trade. Since reform and opening up, China has encouraged all kinds of enterprises to direct invest 
in foreign countries to expand overseas markets and further internationalize themselves. Trade and foreign direct investment have promoted the rapid growth of China's economy, and China expects to turn itself from a large manufacturer to a strong manufacturer by 2025 . In response, the U.S. threatens to launch a trade war, partly because it intends to delay China's effort to become a strong manufacturer and to reduce its trade deficit with China. Donald Trump has invariably regarded China as the top1 "strategic rival", so he has adopted policies to curb China and impose protectionism and defensive measures in areas where Chinese-funded enterprises invest and acquire high-tech and markets. The trade war between the U.S. and China is intensifying, and bilateral economic and trade conflicts will be likely to deteriorate. Since Donald Trump has to face domestic political pressure, punitive measures and continuous negotiations will be an important issue in the future development of bilateral trade relations and will inevitably have an impact on global economic development (Chang, 2018a; Tsai, 2019).

The trade war between China and the U.S. is not just a mere competition between the two major economies, but a manifestation of global geopolitical instability. The bilateral trade dispute has evolved into a bilateral trade war, in which neither side will be a winner and their respective economies and enterprises will suffer. Therefore, the threat of trade sanctions is means, the ultimate goal of which is to force each other to compromise or concede through negotiation to reduce the trade deficit. The trade war not only concerns the U.S. economic interests. The high protective tariff imposed amid the trade war will pile up the cost of foreign-funded enterprises operating in China and reduce their profits. It can eventually accelerate the transfer of foreign-funded industries back to the US, ASEAN countries or other production bases. It can also suppress the space of emerging strategic industries covered by the "Made in China 2025" and prevent China from becoming a large technological manufacturer that is capable of threatening the U.S. hegemony (Chang, 2018b). In recent years, the politicization of trade frictions has become increasingly prominent. Regardless of time or country, any trade policy can never be a simple economic issue. The U.S. is no exception. Due to its cultural tradition, political system and other factors, the U.S. is more likely to politicize China's trade issues than other countries. Its trade policy is essentially the combination of economic interests and political reality, and the result of the balance of various forces in the political arena (Hu, 2006). Chang (2018b) mentioned that there are six possible counter-measures by China against the U.S., including trade retaliation, trade relief, civil anti-American movement, rectification of American businesses in Mainland, financial sanctions and negotiation. Among them, four retaliatory measures have been taken at present, including trade retaliation, trade relief, civil anti-American movement and negotiation, without implementing the rectification of American businesses in Mainland or financial sanctions, and the date when the list of additional tariff on American products takes effect has not yet been announced. China resorts to the above-mentioned counter-measures aiming to bring the Trump Administration back to the negotiating table. In addition, both the Chinese and the U.S. leaders still retain the highest-level contact as a stage to release goodwill, and both sides are believed to prevent trade conflicts from intensifying through negotiation.

Kao (2018a) indicated that the Sino-U.S. trade war is an opportunity for Taiwan; that is to say, when the U.S. is rebuilding the value chain of next-generation industries, it needs to cooperate and go hand in hand with partners with solid strength and industrial technological foundation. Given the "Made in China 2025" targeted by the Section 301 Investigation, China is unlikely to be deemed by the U.S as a priority partner. By contrast, Taiwan, Japan and South Korea boast a better base for cooperation. As a foreign trade-oriented economy, Taiwan is highly dependent on China's manufacturing industry. Due to the notable regional positioning of Taiwan's products, whether Taiwan can achieve positive benefits in the Sino-U.S. trade turmoil remains unknown. It is still necessary to track the re-distribution of global industrial supply chain and international division of labor (Wu, 2018). In order to face the pressure of additional tariff by the U.S. on products manufactured in Mainland, Taiwanese businesses with factories in both Mainland and Taiwan should first adjust the distribution of cross-strait production capacity within the group and transfer the manufacturing of U.S. products to factories in Taiwan (Su, 2019). If China makes concessions in response to the trade deficit between the U.S. and China, it will expand the purchase of American semiconductors. As a result, Taiwan and South Korea's semiconductor industries may suffer from the effect of order transfer. Taiwanese enterprises, which are highly dependent on China and the U.S., must think ahead of time about the countermeasures, strategically adjust the global supply chain layout, speed up automation, accelerate supply chain transfer through mergers and acquisitions, and strengthen transnational management capabilities in order to reduce the negative impact of trade frictions. Considering the comparative advantage, Taiwanese businesses used to increase their production investment in Mainland. After China's accession to the WTO, Taiwanese businesses in Mainland have been increasing their investment and becoming more technologically intensive. Only after being affected by the fueling Sino-U.S. trade war have many Taiwanese businesses begun to rethink about their global layout (Chang, 2018b). 
As different industries in Taiwan have drastically different global distribution patterns, if we want to have a profound understanding on the impact of the Sino-U.S. trade war, we need to start with the role of individual Taiwanese businesses and industries in the global supply chain. Generally speaking, for Taiwanese businesses who adopt the Sino-US-Taiwan triangular trade mode will be impacted if their products are included in the U.S. taxation list. If we only take the sanction list issued in the Sino-U.S. trade war into account, the impact on Taiwan's manufacturing industry is indeed limited. Many Taiwanese enterprises are mainly intermediary agents, most of whom invest in Mainland. Amid the Sino-U.S. trade war, the Taiwanese government should guide Taiwanese businesses to invest in Southeast Asia or South Asia through the "New Southward Policy". Meanwhile, the "5+2" industrial innovation policy should be supplemented to encourage Taiwanese businesses to return to the Island, guarding against the future risk of new protectionism. In addition, trade negotiations among countries still take political power into account, especially in the competition for international political and economic power between the U.S. and China. The exchange of interests will make the situation more rapidly changing, an issue meriting the continuous attention and evaluation of the Taiwanese government. There is room for cooperation between Taiwan and the U.S. in new economic fields such as AI, big data, Internet and financial technology. The Taiwanese government should promote the integration of Taiwan-U.S. industrial chain in new economic fields through orderly project planning. On the one hand, such integration can reduce the impact of the Sino-U.S. trade war on Taiwan; on the other hand, it can contribute to Taiwan's industrial upgrading and transformation. While promoting the "New Southward Policy", Taiwan should seize the opportunity to align itself with China's Belt and Road Initiative. Not only can such cooperation create greater space for Taiwan's economy and industries, but also prevent Taiwan from unilateralism in international politics. In addition, we should accelerate the promotion of "New Southward Policy" to scatter export risks. The notable growth potential of Southeast Asian countries is the focus of governments and enterprises at present. Bilateral cultural and economic and trade exchanges between Taiwan and countries included in the "New Southward Policy" have built a solid foundation. In addition, the layout that is set up by Taiwanese businesses for years contributes to dispersing the impact of the Sino-U.S. trade war (Chang, 2018a; Lin, 2018b).

At present, the trade war between the U.S. and China shows a tendency to bilateralism. China resorts to WTO for the trade war between the U.S. and China, but WTO may not be able to solve this dispute because of the huge scale of bilateral trade war and the large number of products involved. However, despite the pessimistic view that WTO cannot fundamentally solve the trade problem between China and the U.S., WTO still plays a role in this trade war. It remains unclear whether WTO can effectively assist the negotiation between the two sides, solve the problem peacefully, effectively resolve disagreement and dispute on trade, and put an end to the trade war between the U.S. and China while maintaining the global economic development and minimizing the harm. Taiwan boasts a deep economic and trade relation with Mainland the U.S. If the future multilateral trade structure of WTO can gain a more important status due to the trade war between the U.S. and China, Taiwan will also have access tomore business opportunities through WTO. Taiwan should resort to the global trade dispute settlement mechanism (Kao, 2012b; Lai, 2018; Lin, 2018a; Lin, 2018b) advocated by WTO and APEC.

\section{Acknowledgement}

This research is supported by the National Chin-Yi University of Technology, Taiwan, R.O.C. (under Project: NCUT 19-R-MB-025).

\section{References}

Chang, H. (2018b). Development of Sino-US Trade War and Its Impact on Asia-Pacific Regional Economic

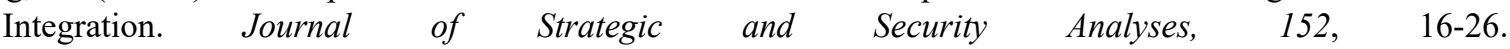
https://doi.org/10.30382/SSA.201810_(152).0002

Chang, H. (Ed.). (2018a). Analyzing the Trend and Impactof US-Sino Trade War. Foundation on Asia-Pacific Peace Studies. Retrieved fromhttps://www.faps.org.tw/files/5846/86117B9A-E73D-4652-8979-29CE70942B1A

Hu, J. (2006). Political and Economic Analysis on Sino-US Trade Friction. Economic Tribune, 21, 48-50. Jia, K. (2018).Analysis on China's Modernization Strategy of "Catching up as a Late Comer", From the Perspective of the Sino-US Trade War. Sub National Fiscal Research, 2018(3), 48-53.

Kao, J. (2018a). Sino-US Trade War and Its Possible Impact on Taiwan's Industries. Journal of Strategic and Security Analyses, 150, 59-68. https://doi.org/10.30382/SSA.201806_(150).0006

Kao, P. (2010). A Complex Interdependence: China-US Relations. In S. Guo \& B. Guo, (Eds.), Thirty Years of China - US Relations: Analytical Approaches and Contemporary Issues. New York: Lexington. 
Kao, P. (2012a). US-China Trade Bargaining under the WTO Regime: A Case Study of Intellectual Property Rights. Chinese Political Science Review, 53, 29-45. https://doi.org/10.6229/CPSR.2012.53.02

Kao, P. (2012b). The Role Played by International Regimes in US-China Trade Bargaining: An Example of the WTO. Journal of Humanities and Social Sciences of NHCUE, 5(2), 163-182. https://doi.org/10.29895/ATFSAS.201209.0005

Kao, Y. (2018b). How Does Taiwan Respond to the Sino-US Trade War? Taiwan Economic Research Monthly, 41(7), 115-121. https://doi.org/10.29656/TERM

Lai, Y. (2018). The Role of the WTO in the US-China Trade War. Review of Global Politics, 64, 15-22. https://doi.org/10.29899/JRM

Li, W. (2018). The Impact of RMB Devaluation on Taiwan and Its Response in Sino-US Trade War. Accounting Research Monthly, 394, 20-25. https://doi.org/10.6650/ARM

Lian, W. (2019). Analysis and Prospect of International Economy of 2018-2019. Economic Outlook Bimonthly, 181, 20-27. https://doi.org/10.30071/EOB

Lin, C. (2018a). "WTO Multilateral Framework",a Good Opportunity to Resolve Sino-US Trade War. Taiwan Economic Research Monthly, 41(6), 8-9. https://doi.org/10.29656/TERM

Lin, C. (2018b). Countermeasures Are Immediately Needed for Sino-US Trade War. Taiwan Economic Research Monthly, 4l(11), 8-9. https://doi.org/10.29656/TERM

$\mathrm{Su}$, C. (2019). Impact of Sino-US Trade War on Operation of Taiwanese Businesses in Mainland and Their Response. Economic Outlook Bimonthly, 181, 103-107. https://doi.org/10.30071/EOB

Tsai, C. (2019). US-China Competition and the Belt and Road Initiative: A Perspective of Power Based on Global Network Culture. Prospect Quarterly, 20(1), 1-60. https://doi.org/10.7063/PQ

Wang, I. (2018). WTO Controversy on Trump Administration's Launching "301 Investigation" on Chinese Mainland. Economic Outlook Bimonthly, 177, 92-96. https://doi.org/10.30071/EOB

Wu, L. (2018). Progress and Impact of Sino-US Trade War. Economic Outlook Bimonthly, 179, 47-52. https://doi.org/10.30071/EOB

Yan, H. (2018). Development and Possible Evolution of Sino-US Economic and Trade Confrontation. Economic Outlook Bimonthly, 177, 87-91. https://doi.org/10.30071/EOB

\section{Copyrights}

Copyright for this article is retained by the author(s), with first publication rights granted to the journal.

This is an open-access article distributed under the terms and conditions of the Creative Commons Attribution license (http://creativecommons.org/licenses/by/4.0/). 